\title{
CHRONIC PROGRESSIVE EXTERNAL OPHTHALMOPLEGIA
}

\author{
I. A QUANTITATIVE HISTOCHEMICAL STUDY OF SKELETAL MUSCLES
}

ELZA DIAS-TOSTA *

SUMMARY - This study quantitates the major morphological and cytochemical changes in limb muscle biopsies from 37 patients with the syndrome of chronic progressive external ophthalmoplegia (CPEO). The aim was to assess the value of limb muscle biopsy in the diagnosis of this syndrome; to define the myopathological changes and to determine whether there were any specific clinico-pathological correlations. Patients were divided into three clinical groups - 11 patients with CPEO with facial and/or limb muscle weakness; 10 with CPEO with tacial and/or limb muscle weakness and a positive family history; 16 with CPEO with one or more of the following: pigmentary retinopathy, cerebellar ataxia, pyramidal signs and peripheral neuropathy. The following parameters were measured: the proportions of histochemical fibre types, the muscle fibre areas and the percentage of muscle fibres showing increased oxidative enzyme activity. Pooled results for each of the clinical categories were compared. Statistical analysis of fibre areas and the percentage of fibres with increased oxidative enzyme activity, showed that group 2 differed from the others $(p<0.05)$. Patients in group 2 showed the highest incidence of type 1 fibre hypertrophy, type $2 \mathrm{~A}$ atrophy and the lowest incidence of fibres with increased oxidative activity. Fibre type disproportions occurred in all three froups but the differences were not significant.

\section{Oftalmoplegia externa crônça progressiva: I. Estudo histoquímico quantitativo de músculos} esqueléticos.

RESUMO - Estudaram-se quantitativamente as aiterações morfológicas e histoquímicas de biópsias de músculos dos membros superiores ou inferiores em 37 pacientes com a sindrome de oftalmoplegia externa crỏnica e progressiva (OECP), o objetivo era determinar o valor da bínsia do músculo esquelético dos membros no diagnóstico desta síndrome, definir as alterações miopatológicas e determinar se havia alguma cơrrelação clínico-patológica específica. Os pacientes foram classificados em très grupos clínicos: 11 pacientes com OECP mais fraqueza de musculatura facial e/ou de membros; 10 pacientes com OECP, fraqueza muscuiar e história familiar positiva; 16 pacientes com OECP, fraqueza muscular e um ou mais dos seguintes sinais - retinopatia pigmentar, ataxia cerebelar, sinais piramidais e neuropatia periférica. Os seguintes parâmetros foram avaliados: proporção de tipos histoquimicos de fibras musculares, áreas destas fibras, percentagem de fibras mostrando aumento de atividade enzimática oxidativa. Os resultados foram comparados entre os três grupos definidos clinicamente. Análises estatisticas das áreas das fibras e da percentagem de fibras com aumento da atividade enzimática oxidativa, mostram que 0 grupo 2 difere dos demais (p $<0,05$ ). Os pacientes do grupo 2 mostraram a mais alta incidência de hipertrofia de fibras do tipo 1 , atrofia do tipo $2 \mathrm{~A}$ e a mais baixa incidencia de fibras com aumento da atividade oxidativa. A desproporçâo de tipos de fibras ocorreu nos três grupos, mas sem diferença significativa.

Muscle Histochemistry Laboratory, National Hospital for Nervous Diseases, University of London, Queen Square, London, England: * M.D., Ph.D. 
Chronic progressive external ophthalmoplegia (CPEO) is a descriptive term which has been applied to a group of patients who present with slowly progressive ptosis and limitation of ocular movements but with normal pupillary responses to light and convergence. They show no evidence of exophtalmos and the symptoms and signs do not show any significant fluctuation. Classical histopathological techniques did not permit the delineation of distinct pathological entities within the group of CPEO patients. With the additional aid of histochemistry and electronmicroscopy it became possible to identify some distinct morphological features such as mitochondrial abnormalities 9,19 and rimmed vacuoles 8 . The mitochondrial abnormalities have been shown in the group of CPEO patients with multisystem involvement 7,15 while the presence of rimmed vacuoles was used to characterize the group of oculopharyngeal dystrophy 8 .

The aim of this study was to obtain quantitative histochemical data on the myopathological changes in a group of patients presenting clinically with CPEO. It was intended to use such data to: define the value of limb muscle biopsies in the diagnosis of this syndrome; describe and define the myopathological changes; determine whether this syndrome constitutes one or more clinico-pathological entities. Quantitative electronmicroscopy data will be reported in a subsequent paper.

\section{MATERIAL AND METHODS}

Patients - Thirty-seven patients with CPEO were studied. Eleven of them were selected because they were sporadic cases with slowly progressive ptosis and weakness of external ocular muscles, without pupiliary changes cr significant diplopia. Ten other cases presented similar clinical features but had a positive family history. The other 16 cases exhibited one or more of the following additional features: atypical pigmentary retinopathy, cerebellar ataxia, pyramidal signs, peripheral neuropathy and cardiac conduction defects.

Muscle biopsies - Open biopsies were taken from one of the following limb muscles: 19 triceps, 9 biceps, 5 extensors in the forearm, 2 deltoid, 2 quadriceps. All samples were rapidly frozen in isopentane, cooled in liquid nitrogen, and cryostat sections $5-10 \mu \mathrm{m}$, stained with the modified Gomori trichrome method (10), succinic dehydrogenase (1 $)$, PAS, Sudan black, DPNH-tetrazolium reductase (18), and menadione-linked $\alpha$-glycerophosphate dehydrogenase (20). The myofibrillar adenosine triphosphatase (ATPase) reactions were used to identify the three major histochemical fibre types $(4, \tilde{j})$. Quantitative studies - 33 specimens were suitable for quantitative studies. Fibres with increased oxidative enzyme activity, as shown by the succinic dehydrogenase reactions, were unevenly distributed throughout the sections. For quantitative studies, the area with the highest density of these fibres was selected in each case and photogranhed. From these areas a sample of 100 muscle fibres was counted, and the percentage of those with increased oxidative enzyme activity was determined. These fibres were typed by comparison with similar areas in sections stained by ATPase reactions. The proportions of the three histochemical fibre types were determined in printed photographies of 3 to 6 different areas from sections stained with the myofibrillar ATPase reactions (at $\mathrm{pH} 4.4,4.5$ or 4.6 ). The total area examined in each biopsy contained from 294 up to 348 fibres. The individual area of each muscle fibre was measured on the same sample used for determining the proportions of the histochemical fibre types. These measurements were made with the Reichert Manual Ontical Analysis System AMO3 (MOP system), and mean dianeters were calculated from these areas. The reproducibility of the method of measurement was tested when: different magnifications of the same photographed area were used: the same observer measured the area twice; different observers measured the same area. The results were shown to be reproducible. Comparison between mean diameters obtained by our method using the MOP system and those obtained with the «lesser» diameter (8) were made. In view of the consistently larger fibre diameters ranges obtained using the MOP system of measurement, normal ranges for fibre diameters were considered as 40-80 $\mu^{\mathrm{m}}$ for women, and from 50-90 $\mu_{\mathrm{m}}$ for men.

Data analysis - The following data were determined from each muscle: the percentage of each fibre type, the mean fibre diameter for each fibre type, together with their ranges, standard deviations (SD), standard errors (SE) and relative standard errors (RSE). Histograms of the fibre sizes were constructed, and atrophy factors (AF), hypertrophy factors (HF) and variability coefficients (v.c.) were calculated for each sample $(2,3)$, The proportions of fibres larger and smaller than the limits considered as normal were also calculated. The clinical, morphological and histochemical data were compared. For the normally distributed 
variables the following analyses were used: Student's «t» test to compare two means; one way anaiysis of variance for the comparison of more than two means; correlation coefficient (Pearson) to measure the level of linear association between two variables. Variables with a non-normal distribution were compared by using the Spearman rank correlation coefficient and the Kruskal-Wallis one way analysis of variances by ranks.

\section{RESULTS}

On the basis of the clinical features and the family history, patients were divided inte three clinical groups $\rightarrow$ A, sporadic cases with muscle weakness only (11 pattents); $B$, familial cases with muscle weakness only: $10 ; \mathrm{C}$, patients with clinical and laboratory evidence of multisystem disease: 16. The overall clinical findings are presented in Fig 1.

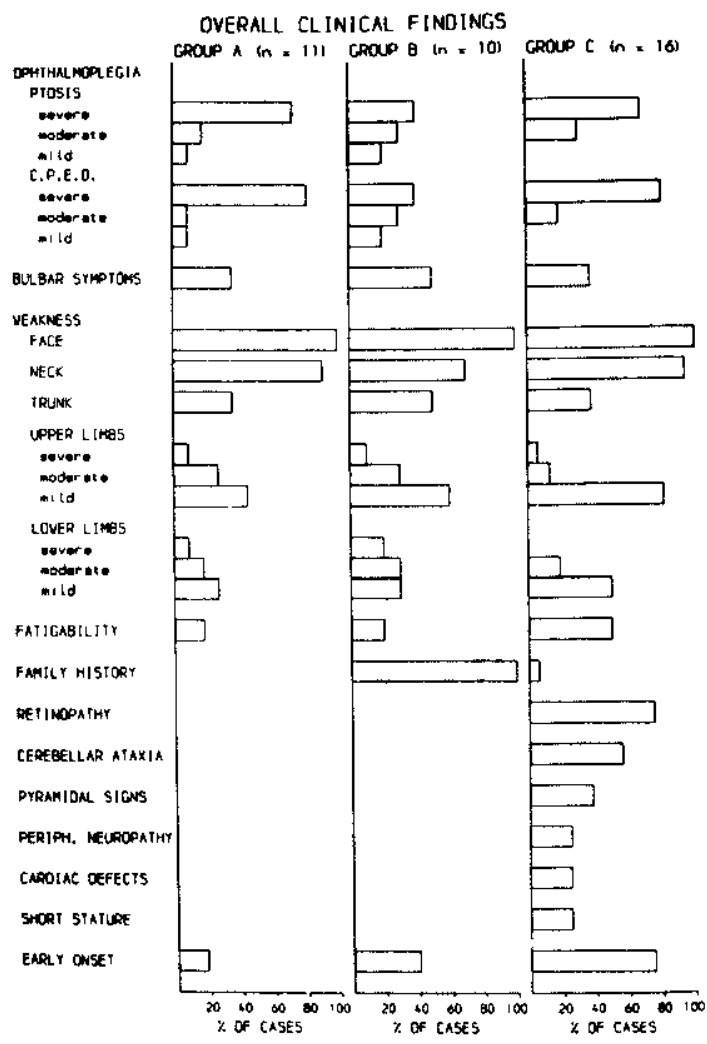

Fig. 1 - The overall clinical findings.

Quantitative lfght microscopy - Fibres showing subsarcolemmal or intermyufibrillar collections of red-staining granular material with the modified Gomori trichrome method («ragged-red» fibres) (Fig. 2a) constituted the most prominent or the exclusive change in 24 out of 37 biopsies. These fibres were shown to possess increased oxidative enzyme activity with succinic dehydrogenase reaction (Fig. 2b), and increased lipid content with Sudan-black. These cytoarchitectural changes were most commonly demonstrated in type 1 fibres, but type $2 \mathrm{~A}$ and $2 \mathrm{~B}$ were also affected. Fibres containing a single or multiple small vacuoles were encountered in 5 blopsies from group $\mathbf{B}$ and one from group $\mathbf{A}$. The vacuoles were surrounded by and contained fine red staining filamentous material, as shown by the modified Gomori trichrome method (Fig. 3). Fibres with disorganization of the intermyofibrillar network («moth-eaten» appearance) were the major change in muscle biopsies from cases $A_{6}$ and $B_{9}$, using oxidative enzyme reactions (Table 1). Small angulated fibres were present in 26 biopsies: 7 in group A, 10 in group $B$ and 9 in group C. In 5 cases 

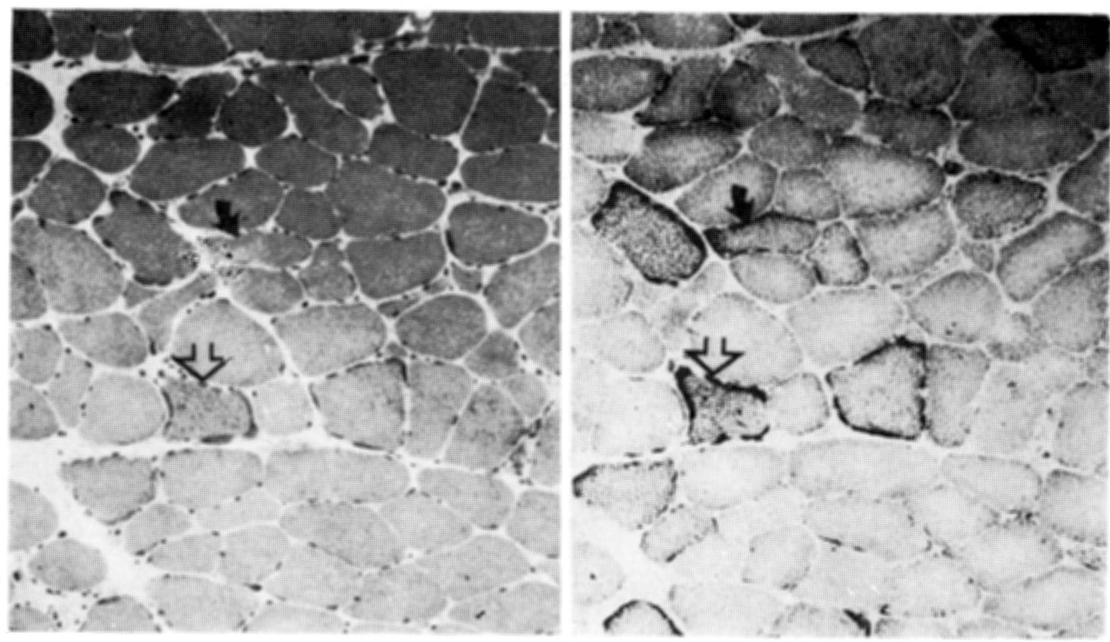

Fig. 2 - Serial sections of the right biceps muscle from a case of group $A$. Left: Gomori trichrome method showing variation in muscle fibre size, increased endomysial connective tissue and fibres with dark-staining material, mainly in the subsarcolemmal position. Right: succinic dehydrogenase reaction to show increased subsarcolemmal activity in some fibres.

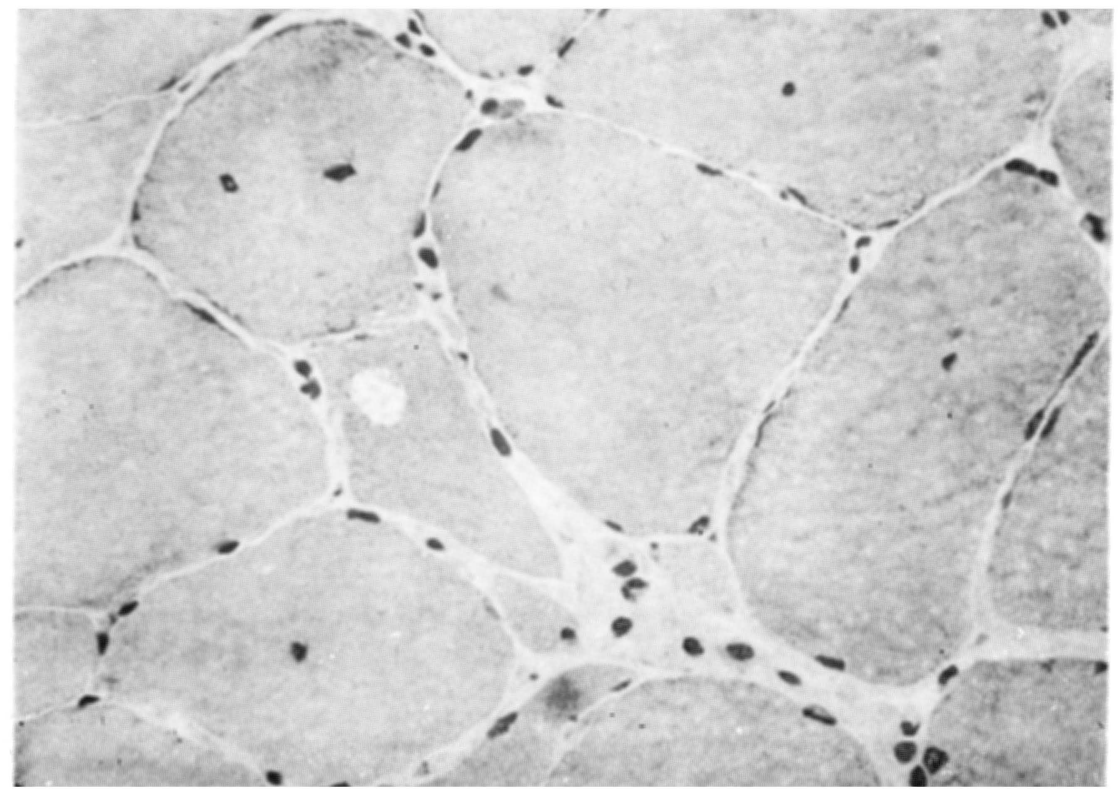

F'ig. 3 - Biopsy from the left biceps from a case of group B showing a small group of atrophic fibres, and a vacuolated fibre (modified Gomori trichrome method) 


\begin{tabular}{|c|c|c|c|c|c|c|c|c|}
\hline \multirow{2}{*}{ Cases } & \multirow{2}{*}{ Muscle* } & \multicolumn{3}{|c|}{ Fibre types } & \multicolumn{4}{|c|}{$\begin{array}{c}\text { Fibres with increased oxidative } \\
\text { enzyme activity }\end{array}$} \\
\hline & & 1 & $2 \mathrm{~A}$ & $2 B$ & 1 & 2A & $2 \mathrm{~B}$ & Total \\
\hline A1 & $\mathbf{B}$ & 92 & 6 & 2 & 19 & - & - & 19 \\
\hline A2 & $\mathbf{B}$ & 37 & 28 & 35 & 5 & 14 & 3 & 22 \\
\hline A3 & $\mathbf{T}$ & 27 & 42 & 31 & 4 & - & - & 4 \\
\hline A4 & $\mathrm{T}$ & 42 & 46 & 12 & - & - & - & - \\
\hline A6 & $\mathrm{D}$ & 71 & 27 & 2 & - & - & - & - \\
\hline A7 & $\mathbf{T}$ & 34 & 39 & 27 & 6 & 3 & - & 9 \\
\hline A8 8 & $\mathbf{T}$ & 24 & 23 & 53 & - & 1 & 1 & 2 \\
\hline A10 & $\mathbf{B}$ & 50 & 24 & 26 & - & - & - & - \\
\hline A11 & $T$ & 64 & 26 & 10 & 20 & 5 & - & 25 \\
\hline B1 & $T$ & 62 & 23 & 15 & - & 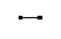 & - & - \\
\hline B2 & $\mathbf{T}$ & 29 & 53 & 18 & - & - & - & - \\
\hline B3 & $Q$ & 79 & 20 & 1 & - & - & - & -- \\
\hline B4 & $\mathbf{E}$ & 98 & 1 & 1 & - & - & - & - \\
\hline B5 & $\mathrm{T}$ & 21 & 46 & 33 & - & - & - & - \\
\hline $\mathrm{B} 6$ & $\mathrm{~B}$ & 74 & 25 & 1 & - & - & - & - \\
\hline $\mathrm{B} 7$ & B & 70 & 26 & 4 & - & - & - & - \\
\hline B8 & $\mathrm{E}$ & 50 & 36 & 14 & 一 & - & - & - \\
\hline B9 & D & 83 & 17 & $<1$ & 3 & - & - & 3 \\
\hline $\mathrm{Cl}$ & $\mathbf{T}$ & 78 & 16 & 6 & 10 & 1 & - & 11 \\
\hline $\mathrm{C} 2$ & $\mathrm{Q}$ & 28 & 35 & 37 & 4 & 1 & - & 5 \\
\hline $\mathrm{C} 3$ & $\mathrm{~T}$ & 41 & 48 & 11 & 1 & 6 & - & 7 \\
\hline $\mathrm{C} 4$ & $\mathrm{~T}$ & 33 & 27 & 40 & 6 & 3 & 1 & 10 \\
\hline C5 & $\mathrm{T}$ & 32 & 37 & 31 & - & - & - & - \\
\hline C6 & $\mathbf{E}$ & 95 & 5 & - & 17 & 5 & - & 22 \\
\hline $\mathrm{C} 7$ & B & 54 & 31 & 15 & 31 & 6 & - & 37 \\
\hline $\mathrm{C} 8$ & $\mathbf{T}$ & 37 & 35 & 28 & 1 & - & - & 1 \\
\hline C10 & $\mathrm{T}$ & 22 & 31 & 47 & - & 2 & 2 & 4 \\
\hline C11 & $\mathbf{T}$ & 36 & 27 & 37 & 9 & $* *$ & $* *$ & 11 \\
\hline $\mathrm{C} 12$ & B & 28 & 21 & 51 & 1 & - & - & 1 \\
\hline $\mathrm{C} 13$ & $E$ & 94 & 5 & 1 & 36 & 3 & - & 39 \\
\hline C14 & B & 61 & 27 & 12 & 4 & 1 & - & 5 \\
\hline $\mathrm{Cl5}$ & $\mathrm{T}$ & 57 & 32 & 11 & 5 & 3 & - & 8 \\
\hline C16 & $\mathbf{T}$ & 74 & 23 & 3 & 7 & 1 & - & 8 \\
\hline
\end{tabular}

Table 1 - Proportions of fibre types and fibres with increased oxidative enzyme activity. $*: B$, biceps; $T$, triceps; $D$, deltoid; $Q$, quadriceps; $E$, extensors in the forearm. $* *: 2 \%$ of fibre type 2 with increased ox:dative enzyme activity. Note: cases A5, A9, B10 and C9 were unsuitable for quantitative studies. 


\begin{tabular}{|c|c|c|c|c|c|c|c|c|c|}
\hline \multirow{2}{*}{ Cases } & \multicolumn{3}{|c|}{ Atrophy } & \multicolumn{3}{|c|}{ Hypertrophy } & \multicolumn{3}{|c|}{ Abnormal v.c. $(250)$} \\
\hline & 1 & $2 \mathrm{~A}$ & $2 \mathrm{~B}$ & 1 & $2 \mathrm{~A}$ & $2 \mathrm{~B}$ & 1 & $2 \mathrm{~A}$ & $2 B$ \\
\hline A1 & + & - & - & + & + & + & + & - & $\mathrm{ND}$ \\
\hline A2 & - & + & - & 一 & - & - & - & - & - \\
\hline A3 & + & -- & + & - & + & $+{ }^{(1)}$ & - & 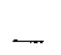 & + \\
\hline A4 & + & + & + & - & - & - & - & - & 一 \\
\hline A6 & - & - & - & - & - & - & 一 & - & ND \\
\hline A7 & - & - & - & - & + & + & - & - & - \\
\hline A8 & + & + & + & - & - & - & - & - & - \\
\hline A10 & - & - & - & + & + & + & - & - & 一 \\
\hline A11 & $\ldots$ & +( & $t^{(3}$ & $\ldots$ & $+^{(1)}$ & - & - & - & - \\
\hline B1 & - & + & + & + & + & - & - & + & - \\
\hline B2 & 一 & - & 一 & $T$ & + & - & - & - & 一 \\
\hline B3 & - & + & - & + & - & + & - & + & ND \\
\hline B4 & - & - & + & $++^{(1)}$ & - & - & - & ND & ND \\
\hline B5 & - & - & - & - & - & - & - & - & - \\
\hline $\mathrm{B} 6$ & - & - & + & + & + & - & - & - & ND \\
\hline B7 & -+ & + & + & - & 4 & - & + & $+r$ & + \\
\hline B8 & - & - & - & + & + & + & - & - & - \\
\hline B9 & - & + & - & + & + & + & - & + & ND \\
\hline $\mathrm{C} 1$ & + & + & + & - & - & - & 一 & - & + \\
\hline $\mathrm{C} 2$ & + & + & + & - & - & - & - & - & 一 \\
\hline $\mathrm{C} 3$ & - & - & - & - & - & - & - & $\cdots$ & - \\
\hline $\mathrm{C} 4$ & - & - & - & $+{ }^{(1)}$ & + & t & - & - & - \\
\hline C5 & - & - & - & - & - & - & - & - & - \\
\hline $\mathrm{C} 6$ & + & + & - & + & + & - & + & + & ND \\
\hline $\mathrm{C} 7$ & - & - & + & - & - & - & - & - & - \\
\hline $\mathrm{C} 8$ & - & - & + & - & - & - & 一 & - & 一 \\
\hline C10 & - & - & - & - & - & - & - & - & - \\
\hline $\mathrm{C} 11$ & + & - & - & - & - & - & - & - & 一 \\
\hline $\mathrm{C} 12$ & - & - & - & - & - & $+{ }^{(1)}$ & - & - & - \\
\hline $\mathrm{C} 13$ & + & - & + & - & $+^{(1)}$ & - & + & - & ND \\
\hline $\mathrm{C} 14$ & - & + & + & - & - & - & - & - & - \\
\hline $\mathrm{C15}$ & + & + & - & - & - & - & 一 & + & - \\
\hline C16 & - & - & - & + & + & + & - & - & - \\
\hline
\end{tabular}

Table 2 - Fibre size abnormalities: atrophy, hypertrophy and variability coefficient (v.c.). (1), $10 \%$ or more of the fibres had abnormal diameters but the corresponding atrophic factors (AF) or hypertrophic factors ( $H F^{*}$ ) were not abnormal. (2), abnormal value for $A F$ or $H F$ but less than $10 \%$ of the fibres outside the normal range. (9), not considered here (extreme deficiency of this fibre type). 
from group $B$ and one from group $A$, the atrophic angulated fibres were darker in DPNHtetrazolium reductase and menadione linked $\alpha$-glycerophosphatase. They were shown with ATPase stains to be of all fibre types. In cases $A_{10}, B_{6}$ and $B_{8}$ these fibres were arranged in small groups. Occasional fibres undergoing necrosis and phagocytosis were seen in 4 cases from group A, three from group B and 5 from group $C$. A slight increase in the amount of endomysial connective tissue was seen in three out of 11 cases from group $\mathbf{A}$, three out of 10 from group $B$ and 4 out of 16 from group $C$.

Quantitative studies - The presence of fibres with increased oxidative enzyme activity was the predominant change in 21 of the 33 cases: 6 from group $A$, one from group $B$ and 14 from group $C$. The percentage of the «ragged-red» fibres ranged from $1 \%$ to $39 \%$ in different cases. In the majority (13 cases) their incidence was between $5 \%$ and $25 \%$ and in 6 cases they contributed less than 5\%, and in two cases more than $30 \%$ of the total fibre count. Fibre type proportions were normal in 18 cases. Type 1 predominance (in these series ranged from $61 \%$ to $98 \%$ ) was always present in those $\mathbf{1 5}$ biopsies with fibre type dysproportion: three cases from group A, 6 from group B and 6 from group C. (Table 1). In no biopsy a complete fibre type uniformity was found.

Fibre measurements - Thirty-three biopsies were studied quantitatively and the abnormal results are listed in Table 2. In biopsies of patients in group $A$ and $C$ some fibres from all three types were found to have atrophy unselective for fibre type. In group $B$, however, atrophy of fibres $2 \mathrm{~A}$ and $2 \mathrm{~B}$ predominated. Only one case showed type 1 atrophy (Table 2). In addition, the three clinical groups differed in regard to the lower range diameter values for type $2 \mathrm{~A}$ fibres, the lowest being found in group $\mathrm{B}$. The type 1 fibre atrophy which occurred in some of our patients from group $A$ and $C$, was neither a constant nor a selective finding.

Data analysis - Preliminary statistical analyses were performed to determine whether a number of differences between biopsies could have influenced the results obtained. The variables tested included: the site of the biopsy (biceps, deltoit, triceps, extensors in the forearm and quadriceps), the side (left or right) of the body from which the muscle specimens were taken, the patient's age at biopsy and the relative proportions of males and females in the samples. From the entire sample $(n=33)$ the following results were obtained One way analysis of variance showed that the site of the biopsied muscle influenced the fibre type proportions. The patient's age at bionsy was positively correlated with the mean fibre sizes. The quantitative data were pooled according to the three clinical groups (A, B and $C)$ and the grouped means were analysed. Because of the results stated above, when comparisons of fibre sizes were made between grouped sets of biopsies, we first examined whether there were age differences between biopsy groups that might influence the results. We also investigated whether the location of the biopsied muscle affected the results when the fibre type proportions were compared. Having certified that the age and the location of the biopsies in those grouped means were not influencing the results, further analysis were carried out between the groups in relation to the quantitative data obtained in light microscopy. The results showed a statistically significant difference $(p<0.05$ ) between the groups in relation to the mean size of type 1 fibre, type 1 fibre hypertrophy factor, the proportion of large type 1 fibres. the lower size ranges of type $2 \mathrm{~A}$ fibre and the proportion of fibres having increased oxidative enzyme activity. In the samples with «ragged-red» fibres the proportion of these fibres correlated positively with the wroportion of type 1 fibre, and negatively with the proportions of type $2 A$ and $2 B$ fibres.

\section{COMMENTS}

On the basis of the quantitative light microscopy criteria, the presence of fibres with increased oxidative enzyme activity in muscle biopsies were indicative of mitochondrial abnormalities. So, on that basis, group $\mathrm{A}$ and $\mathrm{C}$ were considered as homogeneous groups. Two out of three exceptions to that in group A, constituted also exception in relation to the clinical findings, as they did not have limb muscle weakness, although signs of limb muscle involvement in electromyography were present in case $\mathrm{A}_{4}$. Only one exception was observed in group $\mathrm{C}\left(\mathrm{C}_{5}\right)$ whose biopsy was normal on light microscopy. While the majority of muscle biopsies from groups $A$ and $C$ were characterized by the presence of "ragged-red" fibres, in group B the distinct morphological finding was the presence of some fibres with vacuoles. They were observed in 5 out of 10 binnsies in group B and one out of 11 in group A. Similar vacuoles have being reported to occur mainly, but not exclusively, in patients 
with hereditary chronic progressive external ophthalmoplegia 8. Signs of myiopathic changes were present in 4 out of the 6 biopsies, with vacuolated fibres, with the exception of one case $\left(B_{5}\right)$ with very mild clinical involvement. It is suggested that the vacuoles represent the first sign of the degenerative myopathic process in those individual muscle fibres. As in hereditary muscular dystrophies, progress of the disease leads to loss of muscle fibres and their replacement by fat and connective tissue, with consequent clinical weakness. In our series, the advanced stage of this process was present in two cases $\left(B_{6}\right.$ and $\left.B_{7}\right)$. The impression of a myopathic process was reinforced by the abnormal variability coeficient. It was more frequently found in patients from group B and mostly due to variation in the size of fibre type 2A.

Hypertrophy of one or more fibre types was a major feature of biopsies from patients from group B, but was less common in group A and infrequent in group C. Although all fiore types were affected, hyperthophy most commonly involved type 1 and $2 A$. It is possible that the lower incidence of type $2 B$ hypertrophy reflected a deficiency of this fibre type. In addition, the grouped mean size of type 1 fibres differed in the three clinical groups $A, B$ and $C$, the largest mean value being found in group $B$. The difference between the grouped mean fibre sizes appeared not to be influenced by patient's age at the time of biopsy nor to be related to the duration of symptoms. In human pathological material, fibre hypertrophy has been described in denervation with or without reinnervation 1, in some forms of muscular dystrophy, such as fascioscapulohumeral dystrophy 8 , and also in carriers of Duchenne muscular dystrophy 14. In our series of cases, fibre hypertrophy was found in biopsies showing pathological features of myopathy exclusively, in those with pathological features of myopathy and denervation (small groups of atrophic angulated fibres), in cases in which "ragged-red" fibres were the only abnormality, and in cases lacking any other obvious abnormality. The presence of hypertrophy could not be correlated with clinical signs either; being found in clinically normal muscles $\left(A_{7}\right)$, in mildly weak muscles $\left(C_{4}, C_{6}\right)$, and in severely weak muscle $\left(B_{2}, B_{7}\right)$. Furthermore, hypertrophy could not be correlated with duration of disease, being found in muscle biopsies from patients in which the duration of the disease was as short as four years $\left(B_{5}\right)$ or as long as 53 years $\left(B_{2}\right)$. Moreover, no evidence of hypertrophy was found in case $C_{3}$, biopsied 30 years after the onset of symptoms. In Dubowitz and Brooke's series of 9 familial cases of CPEO, 6 had fibre $2 A$ hypertrophy, and one type 1 hypertrophy. It is interesting that in their series the type 1 preferentially showed atrophy.

The three clinical groups differed also in regard to the lower range diameter values for type $2 \mathrm{~A}$ fibres, the lowest being found in group $\mathrm{B}$. The type 1 fibre atrophy which occurred in some of our patients from group A and C, was neither a constant finding, nor the selective fibre atrophy as seen in congenital fibre type disproportion 8 . The special behaviour of type 1 fibres in our group B may be related to both its physiological properties and the nature of the disease process in this syndrome. In groups $\mathrm{A}$ and $\mathrm{C}$, in which there was evidence of mitochondrial abnormalities (fibres with increased succinic dehydrogenase activity) type 1 fibres which depend upon aerobic glycolysis, were generally atrophic. In group B type 2 atrophy appeared to predominate and to be associated with compensatory hypertrophy of type 1 fibres. In group B type 1 predominance was the most frequent disproportion found, and was combined with fibre type 1 hypertrophy in 6 out of 9 cases. This finding may have diagnostic value in this group of genetically determined myopathies. The three cases in group $B$ without fibre type 1 predominance were $B_{2}, B_{5}$ and $B_{8}$. The former was clinically atypical for this group presentation, complaining of excessive fatigability and also had a very early onset of the disease. In case $B_{5}$ the disease was clinically very mild and the muscle biopsy was suggestive of an early stage in the pathological process.

Although it is accepted that fibres type characteristics are influenced by neural activity 6,13 , in the majority of human pathological conditions fibre type 1 predominance has been associated with myopathic processes, mainly those genetically determined 12. Changes in the proportion of fibre type have generally been attributed to either fibre type transformations or to selective fibre type atrophy 12,16. Studies in human muscle 11 have suggested the possibility of interconversion of fibre types 1 and 2 , under some circumstances. In our series fibre type 1 predominance is suggested to arise from conversion of fibre type $2 \mathrm{~B}$ or both $2 \mathrm{~A}$ and $2 \mathrm{~B}$, into type 1 fibres, depending on which fibre type is deficient. The other possible explanation is a selective atrophy of an individual fibre type with a proportional increase in the 
remaining fibre types. However, in cases $A_{1}, A_{6}, C_{16}$ in whose biopsies type 1 predominance was evident, there was no evidence of fibre type $2 \mathrm{~A}$ or $2 \mathrm{~B}$ atrophy or necrosis which would be the expected intermediate stage before fibre disappearance.

In conclusion, clinical evidence has been presented to justify the classification of patients with CHEO in three groups. In these muscle biopsies analyses our data suggest that this series of patients contains two clinicopathological entities: CPEO witn fibres with increased oxidative enzyme activity and CPEO with occasional vacuolated muscle fibres. Features of non-specific myopathy was found in some patients from both groups. The quantitative studies reinforced the clinical and qualitative impression that group $B$ patients are different from the other two groups $(A$ and $C$ ). The group B patients showed the highest incidence of type 1 fibre hypertropliy, the smallest range of size of type $2 \mathrm{~A}$ tibres, and the lowest incidence of fibre with increased oxidative enzyme activity. The clinical differences found between groups $A$ and $C$, and within patients from group $C$ was suggested by the quantitative studies to be due to either a heterogeneity in the disease process or to different degrees of severity of the same disease.

Acknowledgements - I am grateful to Dr. J.A. Morgan-Hughes and Dr. D.N. Landon for their constant interest and helpful criticism during the preparation of this work, and also made available to me the laboratory facilities in their departments. I also like to thank Dr. A. Pullen and Miss E. Paul for their helps with the statistics, Miss M. Ellison for excelent technical assistance. Dr. Tosta was supported during preparation of this work by the Brazilian Government.

\section{REFERENCES}

1. Bernat JL, Ochoa JL - Muscle hypertrophy after partial denervation: a human case. J Neurol Neurosurg Psychiat 41:719, 1978.

2. Brooke MH, Engel WK - The histographic analysis of human muscle biopsies with regard to fibre types: 1. Adult male and female. Neurology 19:221, 1969.

3. Brooke MH, Engel WK - The histographic analysis of human muscle biopsies with regard to fibre types: 2. Diseases of the upper and lower motor neuron. Neurology $19: 378,1969$.

4. Brooke MH, Kaiser KK - Muscle fibre types: how many and what kind? Arch Neurol $23: 369,1970$.

5. Brooke MH, Kaiser KK - Three «Myosin Adenosine Triphosphatase» systems: the nature of their pH lability and sulphydryl dependence. J Histochem Cytochem 18:670, 1970.

6. Buller AJ, Pope R - Plasticity in mammalian skeletal muscle. Philos Soc London (Bioi) $278: 295,1977$.

7. Castaigne P, Laplane D, Fardeau M, Dordain G, Autret A, Hirt L - Myopathie avec anomailes mitochondriales localisees atx fibres de type 1: documents cliniques, histochimiques et ultrastructuraux concernant une forme atrophique diffuse à debut oculaire. Rev Neurol 126:81, 1972.

8. Dubowitz V, Brooke MH - Muscle Biopsy: a Modern Approach. Saunders, Philadelphia, 1973.

9. Engel WK - «Ragged-red fibres» in ophthalmoplegia syndromes and their differential diagnosis. In: Abstracts of the Second International Congress on Muscle Diseases. Excerpta Medica. Amsterdam, 1971, pg 28.

10. Engel WK, Cunninghan CG - Rapid examination of muscle tissue: an improved trichrome method for rapid diagnosis of muscle blopsy fresh frozen section. Neurology 13:919, 1963.

11. Jansson E, Syödin B, Tesch $\mathbf{P}$ - Changes in muscle fibre type distribution in man after physical training. Acta Physiol Scand 104:235, 1978.

12. Lambert CD - Uniform muscle histochemistry; a clínical and biopsy study. Trans Am Neurol Assoc 99:57, 1974. 
13. Lömo $T$ - The role of activity in the control of membrane and contractile properties of skeletal muscle. In: Thesleff $\mathbf{S}$ (ed): Motor Innervation of Muscle. Academic Press, New York, 1976, pg 289.

14. Maunder-Sewry CA, Dubowitz V. - Needle muscle biopsy for carrier detection in Duchenne muscular dystrophy: 1. Light microscopy, histology, histochemistry and quantitation. $J$ Neurol Sci $305,1981$.

15. Morgan-Hughes JA, Mair WGP - Atypical muscle mitochondria in oculoskeletal myopathy. Brain 96:215, 1973.

16. Munsat TL, McNeal D, Waters $\mathbf{R}$ - Effects of nerve stimulation of human muscle. Arch Neurol 33:608, 1976.

17. Nachlas MM, Tsou KC, de Souza E, Cheng CS, Seligman AM - Cytochemical demonstration of succinic dehydrogenase by the use of a new p-nitrophenyl substituted ditetrazole. J Histochem Cytochem 5:420, 1957.

18. Novikoff AB, Shin MY, Drucker J - Mitochondrial localization of oxidative enzymes: staining results with two tetrazolium salts. J Biophys Biochem Cytol 8:47, 1961.

19. Olson W, Engel WK, Walsh GO, Einaugler R - Oculocraniosomatic neuromuscular disease with «rágged-red» fibres: histochemical and ultrastructural changes in limb muscles of a group of patients with idiopathic progressive external ophthalmopleg:a. Arch Neurol 26:193, 1972.

20. Wattenberg $\mathrm{L}$ W, Leong JL - Effects of coenzyme $Q_{10}$ and menadione succinic dehydrogenase activity as measured by tetrazolium salt reduction. $J$ Histochem Cytochem 8: 296,1960 . 